\title{
* Semangat Jihad Dan Kerukunan Antar Umat Beragama
}

\section{Halimah SM, Mochamad Aryadillah}

Fakultas Ushuluddin UIN Jakarta

halimah.sm@uinjkt.ac.id

Abstrak: Beberapa waktu lalu, sekitar tahun 2016 kita semua khususnya umat Islam dikejutkan dengan adanya kesalahan ucapan terhadap ayat suci al-Qur'an oleh gubernur DKI Jakarta "Basuki Tjahaya Purnama" alias Ahok. Ayat tersebut merupakan salah satu ayat dalam surah al-Maidah ayat 51. Karena kejadian tersebut membuat umat Islam bersama-sama bahu-membahu membela atas apa yang telah salah diucapkan oleh Ahok terhadap surah al-Maidah ayat 51. Dari kejadian tersebut, dapat diketahui bahwa perjuangan umat islam itu disebut dengan Jihad atas al-Qur'an surah al-Maidah ayat 51. Jihad sendiri merupakan sebuah perilaku yang dianjurkan, diwajibkan, bahkan disunnahkan oleh Rasulullah SAW. Istilah Jihad dalam umat Islam seringkali dipahami dengan dua pengertian. Pertama, dalam pengertian etimologis bahasa Arab yang artinya bersungguh-sungguh, dan Kedua dalam pengertian terminologis, yakni Jihad dalam konsep hukum Islam, baik didasarkan al-Qur" an, al-sunnah, atau pun ijma' para ulama. Makna Jihad Menurut Istilah : Dalam terminologi syar'i kata jihad mempunyai beberapa makna seperti : Suatu usaha optimal untuk memerangi orang-orang kafir. Penelitian ini mengenai konsep Jihad dan Kerukunan Antar Umat Beragama yang dalam beberapa waktu lalu sempat ramai diperbincangkan. Kerukunan sendiri memiliki arti yang berbeda dengan Jihad. Kerukunan merupakan jalan hidup setiap manusia yang memiliki bagian-bagian dan tujuan tertentu yang harus dijaga bersama-sama, saling tolong menolong, toleransi, tidak saling bermusuhan dan saling menjaga satu sama lain. Penelitian ini bertujuan agar memahami Jihad tidak secara mutlak, karena jika Jihad diatrikan secara mutlak maka pengertian Jihad bisa sama dengan Qatl (membunuh). Dengan demikian penulis mengartikan Jihad dengan berusaha bertahan dari cobaan yang Allah berikan.

\section{Kata Kunci : Konsep Jihad, Kerukunan.}




\section{Pendahuluan}

Umat Islam yang menjadi penduduk bumi sekarang ini diperkirakan satu triliun dari enam triliun manusia yang menempati bumi ciptaan Allah. Kenyataannya umat Islam pada awal millennium ke-3 ini adalah sebagai umat terpinggirkan, tertindas dan terjajah hak-haknya. Hal ini menyebabkan sebagian anggota dari umat yang mempunyai ghirah agama yang tinggi berbekal dengan ilmu yang diperolehnya mencari cara yang tercepat untuk mengembalikan izzah umat, dengan niat berjihad mereka melancarkan serangan-serangan terhadap seluruh kepentingan kekuatan kufur dan syirik dalam bentuk pemboman titiktitik penting simbol kekuatan durjana.

Diskursus terorisme dan Jihad semakin aktual pasca peristiwa 11 september 2001 (11 September), pengeboman world Trade Center (WTC). George W. Bush mengklaim bahwa pelaku pengeboman adalah jaringan islam radikal (Al-Qaeda) yang dipimpinan Usamah bin Ladin. Sebaliknya, kalangan islam radikal menyakini bahwa perbuatan mereka merupakan aktualisasi doktrin Jihad yang di perintahkan dalam islam ${ }^{1}$.

Jihad merupakan istilah dan ajaran yang tidak asing di dalam kehidupan. Apalagi jika ia dikaitkan dengan konteks kehidupan luas, mencakup banyak makna sejauh kesepakatan suatu kelompok yang menyepakatinya, baik di kalangan media massa maupun media cetak dan elektronik. Di Indonesia, sejak berlangsungnya kasus Bom Bali juga kasus Azhari, istilah Jihad menjadi marak kembali sehingga sering dikutip berbagai media, untuk memberi konteks pada munculnya gerakan-gerakan perlawanan yang dilakukan oleh sebagian kelompok kegamaan terhadap lainnya secara tidak adil ${ }^{2}$. Media massa tidak jarang memberikan ulasan munculnya berbagai aksi pengeboman di berbagai tempat di Indonesia, sebagai bentuk perlawanan kelompok Islam terhadap kelompok lainnya.

Banyak ayat yang berbicara ttg jihad, untuk mengetahui ketentuan jihad yang telah dituntunkan oleh Rasulullah Saw. maka hal itu dapat dipelajari secara rinci dan teraktualisasikan dalam Hadis Rasulullah Saw. secara menyeluruh bukan sepotong-sepotong. Hadis tentang topik tertentu, misalnya tentang jihad jika dipahami secara parsial akan berakibat pada pemahaman yang keliru dan tidak utuh. Dalam realitas yang muncul pada saat sekarang, sebagian orang memahami bahwa jihad tersebut lebih berkonotasi pada tindakan yang menggunakan kekuatan, senjata atau pun tindakan bom bunuh diri dan kekerasan lainnya, sehingga diklaim pelakunya orang Islam, dengan alasan bahwa mereka sedang melakukan jihad yang diperintahkan oleh agama. Pemahaman yang seperti ini, jika dibiarkan terus akan merugikan Islam dan 
umat Islam itu sendiri.

Tulisan ini bertujuan untuk memberikan pengetahuan tentang pemahaman hadits yang seutuhnya dan sesuai dengan konteksnya (maudhu'i). Dengan demikian, pemahaman terhadap jihad tidak akan terjebak pada satu atau beberapa hadits saja dengan meninggalkan hadits lain yang juga membahas masalah yang sama.

\section{Pengertian Jihad}

Istilah Jihad dalam umat Islam seringkali dipahami dengan dua pengertian. Pertama, dalam pengertian etimologis bahasa Arab yang artinya bersungguh-sungguh ${ }^{3}$. Kedua, dalam pengertian terminologis, yakni Jihad dalam konsep hukum Islam, baik didasarkan al-Qur"an, al-sunnah, atau pun ijma" para ulama. Makna Jihad Menurut Istilah : Dalam terminologi syar' i kata jihad mempunyai beberapa makna seperti : Suatu usaha optimal untuk memerangi orang-orang kafir.

Jika diteliti dari akar katanya dalam bahasa Arab, kata jihad berasal dari akar kata jahada (جهد) , jahdan (جهدا) atau juhdan (جهدا) . Adapun jihad berkedudukan sebagai masdar ( kata benda) dan pada ( jahada, yaitu bab fa" ala yang diartikan sebagai " berusaha menghabiskan segala daya kekuatan, baik berupa perkataan maupun perbuatan ${ }^{4}$.

Dari segi bahasa, terma Jihad dalam Al-Qur"an dengan sejumlah kata turunanya berasal dari kata jahd atau juhd. Kata jahd dalam Al-Qur"an terulang sebanyak lima kali" , sedangkan kata juhd hanya 1 kali saja ${ }^{6}$. Kata jahd biasanya di terjemahkan dengan sungguh-sungguh atau kesungguhan, letih atau sukar ${ }^{7}$ dan sekuat-kuat ${ }^{8}$. Adapun kata jubd biasanya diterjemahkan dengan kemampuan', kesanggupan daya upaya dan kekuatan ${ }^{10}$.

Namun Jihad dapat pula diartikan sebagai: penyuruan (ad-dakwah), menyuruh kepada yang ma"ruf dan mencegah kemungkaran (Amar Ma"ruf Nahi Munkar), penyerangan (Ghazwah), pembunuhan (Qital), peperangan (Harb), penaklukan (Syiar), menahan hawa nafsu (Jihad $A n$-Nafs), dan lain yang semakna dengannya ataupun mendekati ${ }^{11}$.

Sedangkan menurut para ulama bagaimana makna jihad adalah :

\section{Madzhab Hanafi}

Menurut mazhab Hanafi, sebagaimana yang dinyatakan dalam kitab Badaa'i As-Shanaa'i, "Secara literal, jihad adalah ungkapan tentang pengerahan seluruh kemampuan. Sedangkan menurut pengertian syariat, jihad bermakna pengerahan seluruh kemampuan 
dan tenaga dalam berperang di jalan Allah, baik dengan jiwa, harta, lisan ataupun yang lain.

\section{Madzhab Maliki}

Adapun definisi jihad menurut mazhab Maaliki, seperti yang termaktub di dalam kitab Munah al-Jaliil, adalah perangnya seorang Muslim melawan orang Kafir yang tidak mempunyai perjanjian, dalam rangka menjunjung tinggi kalimat Allah SWT. atau kehadirannya di sana (yaitu berperang), atau dia memasuki wilayahnya (yaitu, tanah kaum Kafir) untuk berperang. Demikian yang dikatakan oleh Ibn Arafah ${ }^{12}$.

\section{Madzhab Syafi'i}

Madzhab as-Syaafi" $i$, sebagaimana yang dinyatakan dalam kitab al-Iqnaa" yang di kutip dalam kitab Haasyiyah al-Bujayrimi "alaa Syarh al-Khathiib, mendefinisikan jihad dengan "berperang di jalan Allah"'3. Al-Siraazi juga menegaskan dalam kitab al-Muhadzdzab;sesungguhnya jihad itu adalah perang.

\section{Madzhab Hanbali}

Sedangkan madzhab Hanbali, seperti yang dituturkan di dalam kitab al-Mughniy, karya Ibn Qudaamah, menyatakan, bahwa jihad yang dibahas dalam kitaab al-Jihaad tidak memiliki makna lain selain yang berhubungan dengan peperangan, atau berperang melawan kaum Kafir, baik fardlu kifayah maupun fardlu ain, ataupun dalam bentuk sikap berjaga-jaga kaum Mukmin terhadap musuh, menjaga perbatasan dan celah-celah wilayah Islam. Dalam masalah ini, Ibnu Qudamah berkata : Ribaath (menjaga perbatasan) merupakan pangkal dan cabang jihad ${ }^{14}$. Beliau juga mengatakan: Jika musuh datang, maka jihad menjadi fardlu ,ain bagi mereka. Jika hal ini memang benar-benar telah ditetapkan, maka mereka tidak boleh meninggalkan (wilayah mereka) kecuali atas seizin pemimpin (mereka). Sebab, urusan peperangan telah diserahkan kepadanya.

Konsep Jihad dalam pertumbuhannya mempunyai banyak makna dan cakupan mulai dari berjuang melawan hawa nafsu sampai mengangkat senjata ke medan peperangan. Namun, ada substansi Jihad yang bisa dibenarkan oleh hampir semua ulama, yaitu memahami Jihad sebagai suatu seruan kepada agama yang hak. Jika kata Jihad dikaitkan dengan fi sabilillah (di jalan Allah), 
maka Jihad fi sabilillah berarti berjuang di jalan Allah. Jadi Jihad dalam arti di atas adalah perjuangan, dan perjuangan tersebut bisa dilakukan dengan tangan atau lisan untuk mempertahankan agama Allah. Seperti dalam sebuah hadits sebagai berikut:

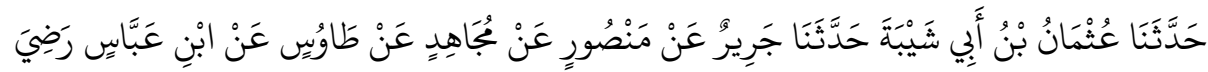

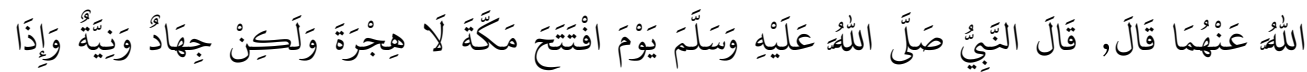

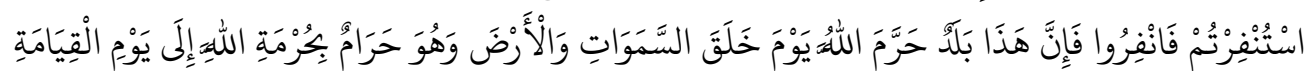

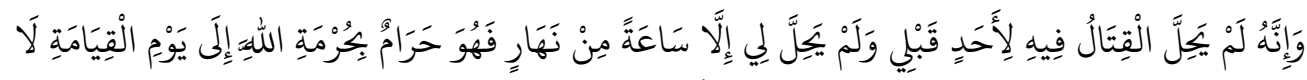

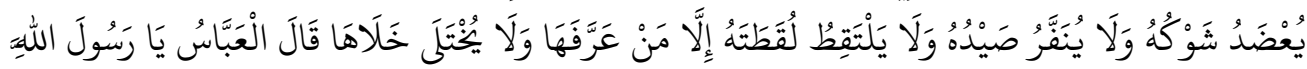

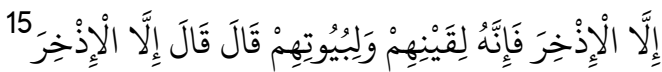

Artinya : Telah menceritakan kepada kami Utsman bin Abu Syaibah, telah menceritakan kepada kami Jarir dari Manshur dari Mujahid dari Thawus dari Ibnu 'Abbas r.a berkata ; Nabi SAW bersabda pada hari pembebasan kota Makkah: "Tidak ada lagi hijrah tetapi yang ada adalah jihad dan niat jika kalian diperintahkan berangkat perang maka merangkatlah. Sesungguhnya negeri ini telah Allah Ikrarkan kesuciannya sejak penciptaan langit dan bumi. Maka dia akan terus suci dengan pensucian dari Allah itu hingga hari kiamat sehingga tidak dibolehkan perang didalamnya buat seorangpun sebelum aku dan tidak dihalalkan pula buatku kecuali sesaat dalam satu hari. Maka dia suciengan pensucian dari Allah itu hingga hari kiamat, dan tidak boleh ditebang pepohonannya dan tidak boleh diburu hewan buruannya dan tidak ditemukan satupun barang temuan kecuali harus dikembalikan kepada yang mengenal (pemilik-NYA) dan tidak boleh dipotong rumputnya". Berkata Al-'Abbas r.a: "Wahai Rasulullah SAW, kecuali pohon dzikir yang berguna untuk wewangian tukang besi mereka dan rumahrumah mereka". Dia berkata, maka beliau bersabda: "Ya, kecuali pohon dzikir".

Dalam hadits diatas terdapat sabda yang kalimatnya berbunyi : "Tidak ada lagi hijrah tetapi yang ada adalah jihad dan niat". Penggalan kalimat dari hadits tersebut mengindikasikan seruan untuk berjihad fisabilillah (menurut para mujahid teroris), padahal dalam teorinya penggalan atau pemotongan kalimat hadits yang dijadikan hokum terkadang tidak diperbolehkan. Mungkin ini siasat bagi para teroris untuk mencuci bahkan mendoktrin para mujahid agar mereka bisa melancarkan serangan pada target yang telah ditentukan.

Ada juga beberapa hadits yang menjelaskan jihad sebagai sebuah anjuran, kewajiban, bahkan sunnah dari Rasulullah SAW berikut inilah haditsnya : 


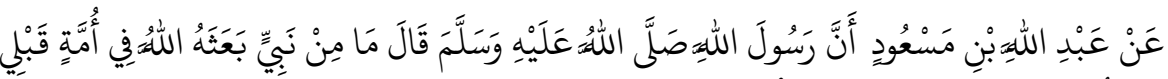

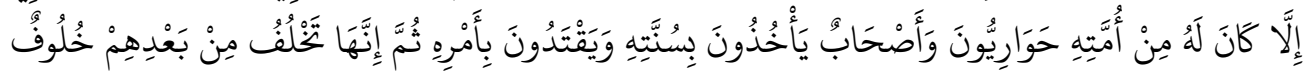

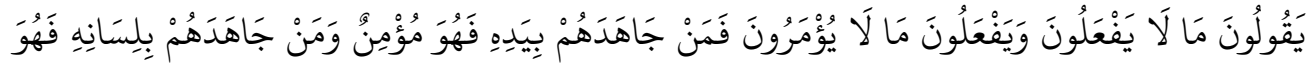

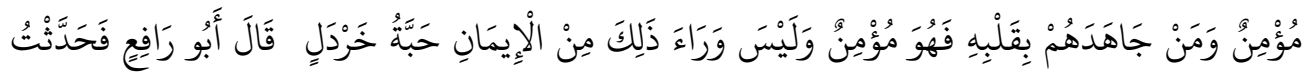

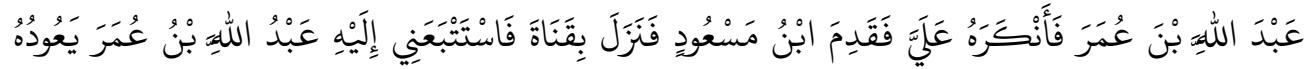

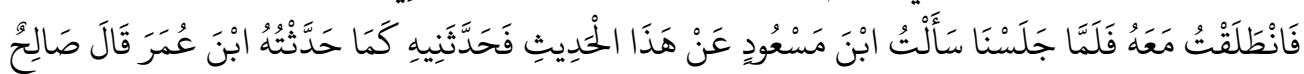

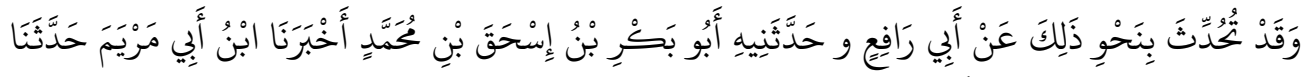

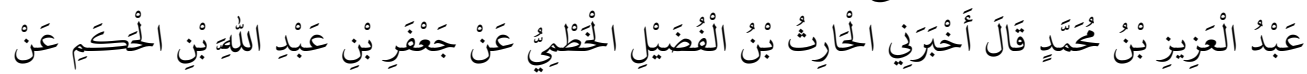

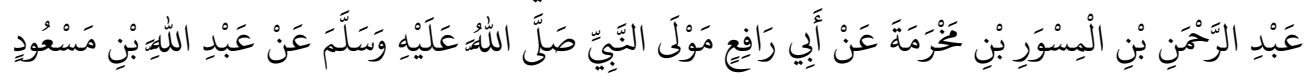

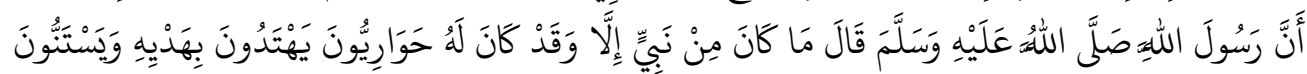

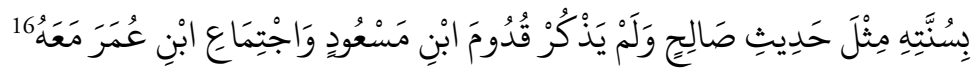

Artinya : dari Abdullah bin Mas'ud bahwa Rasulullah shallallahu 'alaihi wasallam bersabda : "Tidaklah seorang nabi yang diutus oleh Allah pada suatu umat sebelumnya melainkan dia memiliki pembela dan sahabat yang memegang teguh sunah-sunnah dan mengikuti perintah-perintahnya, kemudian datanglah setelah mereka suatu kaum yang mengatakan sesuatu yang tidak mereka lakukan, dan melakukan sesuatu yang tidak diperintabkan. Barangsiapa yang berjihad dengan tangan melawan mereka maka dia seorang mukmin, barangsiapa yang berjihad dengan lisan melawan mereka maka dia seorang mukmin, barangsiapa yang berjihad dengan hati melawan mereka maka dia seorang mukmin, dan setelah itu tidak ada keimanan sebiji sawi." Abu Rafi' berkata, "Lalu aku menceritakan kepada Abdullah bin Umar, namun ia mengingkariku. Ketika Ibnu Mas'ud datang dan singgah pada Qanah, Abdullah bin Umar mengikutiku mengajakku untuk mengikuti Ibnu Mas'ud, maka ketika kami duduk, aku bertanya kepada Ibnu Mas'ud tentang hadits ini, maka dia menceritakannya hadits tersebut kepadaku sebagaimana aku menceritakannya kepada Ibnu Umar." Shalih berkata, "Sungguh telah diceritakan seperti itu dari Abu Rafi". Dan telah menceritakan kepada kami Abu Bakar bin Ishaq bin Muhammad telah mengabarkan kepada kami Ibnu Abu Maryam telah menceritakan kepada kami Abdul Aziz bin Muhammad dia berkata, telah mengabarkan kepadaku al-Harits bin al-Fudlail al-Hathmi dari Ja'far bin Abdullah bin al-Hakam dari Abdurrahman bin Miswar bin Makhramah dari Abu Rafi' mantan budak Nabi shallallahu 'alaihi wasallam, dari Abdullah bin Mas'ud bahwa Rasulullah shallallahu 'alaihi wasallam bersabda: "Tidaklah ada Nabi melainkan dia 
memiliki pembela yang meminta petunjuk dengan petunjuknya, dan mengambil sunnah dengan sunnahnya, " seperti hadits Shalih, namun ia tidak menyebutkan kedatangan Ibnu Mas'ud dan berkumpulnya Ibnu Umar bersamanya."

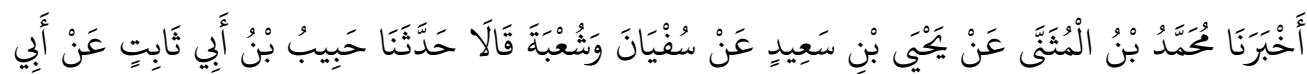

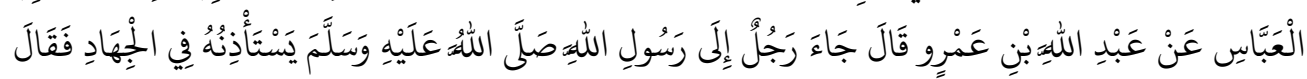

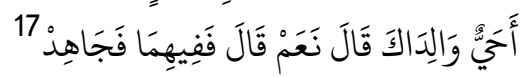

Artinya : Telah mengabarkan kepada kami Muhammad bin Al Mutsanna dari Yahya bin Sa'id dari Sufyan serta Syu'bah mereka berdua berkata; telah menceritakan kepada kami Habib bin Abi Tsabit dari Abu Al Abbas dari Abdullah bin 'Amr, ia berkata; telah datang seorang laki-laki kepada Rasulullah shallallahu 'alaihi wasallam meminta izin kepadanya untuk berjihad, lalu beliau bertanya: "Apakah kedua orang tuamu masih hidup?" Ia berkata; ya. Beliau bersabda: "Berjihadlah pada keduanya".

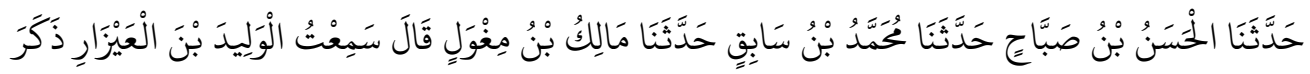

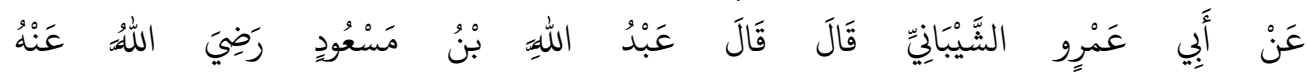

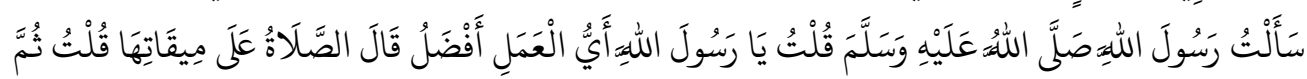

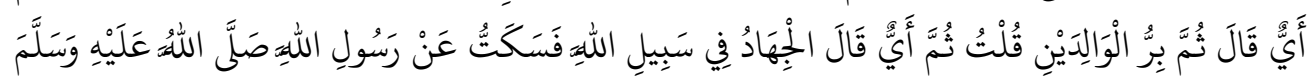

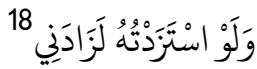

Artinya : Telah bercerita kepada kami Al Hasan bin Shobbah telah bercerita kepada kami Muhammad bin Sabiq telah bercerita kepada kami Malik bin Mighwal berkata; aku mendengar Al Walid bin Al 'Ayzar menyebutkan dari Abu 'Amru Asy Syaibaniy berkata 'Abdullah bin Mas'ud radliallahu 'anhu berkata: "Aku bertanya kepada Rasulullah shallallahu 'alaihi wasallam, aku katakan: "Wahai Rasulullah, amal apakah yang paling utama?" Beliau menjawab: "Sholat pada waktunya". Kemudian aku tanyakan lagi: " Kemudian apa?" Beliau menjawab: "Kemudian berbakti kepada kedua orang tua". Lalu aku tanyakan lagi: "Kemudian apa lagi?" Beliau menjawab: "Jihad di jalan Allah". Maka aku berhenti menyakannya lagi kepada Rasulullah shallallahu 'alaihi wasallam. Seandainya aku tambah terus pertanyaan, Beliau pasti akan menambah jawabannya kepadaku". 


\section{Jihad Dan Penerapannya}

\section{1) Fase-Fase Disyari`atkannya Jihad}

Jihad salah satu diantara ibadah yang dalam proses tasyri nya mengikuti sunnah tadarruj (bertahap), yang dapat kita bagi menjadi 4 fase :

Dalam periode ini jihad dengan mengangkat senjata tidak disyari atkan, yang diperintahkan pada periode ini adalah jihad dengan menggunakan hujjah dan argumen yang bersumber dari Al qur' an dalam menyampaikan risalah Islam kepada manusia pada umumnya dan khususnya masyarakat Quraisy, Allah SWT berfirman:

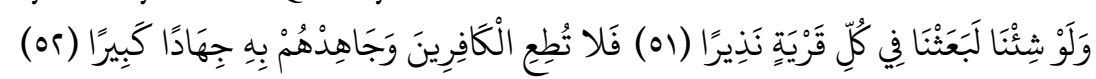

Artinya : "Dan andaikata Kami menghendaki benar-benarlah Kami utus pada tiap-tiap negeri seorang yang memberi peringatan (rasul) (51). Maka janganlah kamu mengikuti orang-orang kafir, dan berjihadlah terhadap mereka dengan Al-Quran dengan Jihad yang besar (52)"19.

Ibnu Qayyim berkata, "Allah telah memerintahkan berjihad sejak periode Mekah dengan firman-Nya (Q.S. Al Furqan: 51-52) yang tentunya surat Makkiyah, menghadapi orang-orang kafir dengan Hujjah, penjelasan dan menyampaikan Al-Qur'an.

Bahkan ketika beberapa orang sahabat yang dipimpin oleh Abdurrahman bin 'Auf datang kepada Nabi mengeluhkan keadaan mereka sambil berkata,"Kami dahulu berada dalam kemuliaan disaat kami masih musyrik, apakah kami menjadi hina setelah kami beriman?!", Nabi menjawab yang artinya, "Aku diperintahkan untuk mema`afkan, maka janganlah kalian mengangkat senjata!".

Juga setelah selesai pembai'atan 'Aqabah yang ke dua sebagian para peserta yang datang dari Yastrib meminta izin dari Nabi untuk menyerang penduduk 'Aqabah dengan pedang, beliau menjawab, "Aku tidak diperintahkan untuk melakukan hal ini", Allah mempertegas larangan mengangkat senjata di periode Makkah, firman-Nya:

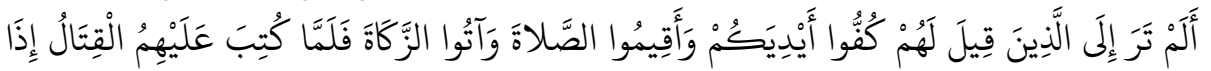

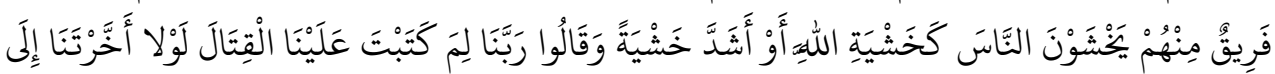

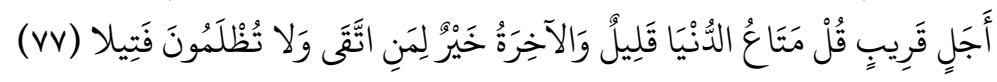

Artinya : "Tidakkah kamu perhatikan orang-orang yang dikatakan kepada mereka "Tahanlah tanganmu (dari berperang), dirikanlah sembahyang dan tunaikanlah zakat!" setelah diwajibkan kepada mereka berperang, tiba-tiba sebahagian dari mereka (golongan munafik) takut kepada manusia (musuh), 
seperti takutnya kepada Allah, bahkan lebih sangat dari itu takutnya. mereka berkata: "Ya Tuhan Kami, mengapa Engkau wajibkan berperang kepada kami? mengapa tidak Engkau tangguhkan (kewajiban berperang) kepada Kami sampai kepada beberapa waktu lagi?" Katakanlah: "Kesenangan di dunia ini hanya sebentar dan akhirat itu lebih baik untuk orang-orang yang bertakwa, dan kamu tidak akan dianiaya sedikitpun"(77) ${ }^{20}$.

Tidak disyaria tkannya jihad mengangkat senjata dalam periode ini yang dalam pandangan kasat mata kebanyakan manusia juga termasuk sebagian sahabat hal itu telah patut karena penindasan kaum Quraisy sampai pada titik diluar batas kewajaran tentulah mempunyai hikmah yang sangat dalam untuk keberlangsungan dakwah Islamiyah keseluruh penjuru bumi.

\section{2) Fase Dibolehkan Jihad Qital dan Belum Difardhukan}

Setelah Rasulullah shallallahu `alaihi wa sallam dan para sahabatnya hijrah ke Madinah, menetap di sana membangun sebuah negeri Islam yang berdaulat dan memiliki kekuatan, persiapan dan peralatan yang dirasa cukup untuk menghadapi setiap gangguan, yang dilain pihak kaum kafir Quraisy selalu melancarkan berbagai bentuk tekanan, maka Allah membolehkan (bukan difardhukan) kaum muslim mengangkat senjata, membela dan mempertahankan jiwa dan dakwah Islam dari segala bentuk penindasan, dengan firman-Nya:

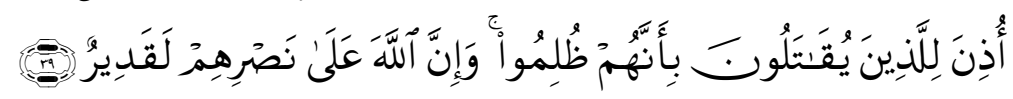

Artinya : "Telah diizinkan (berperang) bagi orang-orang yang diperangi, karena Sesungguhnya mereka telah dianiaya. dan Sesungguhnya Allah, benar-benar Maha Kuasa menolong mereka itu, ${ }^{21}$

\section{3) Fase Difardhukan Jihad Qital Atas Kaum Muslim Terhadap Orang Yang Memulai Memerangi Mereka}

Fase ini juga bisa dinamakan dengan jihad difa' (berperang karena membela diri), yakni kaum muslim diwajibkan mengangkat senjata memasuki medan pertempuran melawan setiap kekuatan yang memulai menabuh genderang perang terhadap mereka, Allah berfirman,

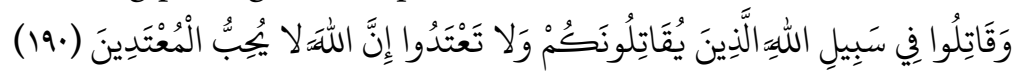

Artinya : Dan perangilah di jalan Allah orang-orang yang memerangi kamu, (tetapi) janganlah kamu melampaui batas, karena Sesungguhnya Allah tidak menyukai orang-orang yang melampaui batas" 22 . 
Pada periode ini sekalipun kaum muslim telah mempunyai kekuatan tetapi belum sanggup memulai pertempuran menghadapi seluruh kekuatan kafir dan musyrikin, maka dengan hikmah Allah, Dia tidak mewajibkan kepada hambanya untuk melakukan penyerangan karena mereka belum mampu melaksanakannya.

4) Fase Difardhukan Jihad Qital Terhadap Setiap Kekuatan Kufur Apapun Agama Dan Ras Mereka, Sekalipun Mereka Tidak Memulai Berperang Hingga Mereka Masuk Islam Atau Membayar Jizyah

Setelah kekuatan kufur di kota Mekah runtuh di tangan 10.000 orang sahabat yang dipimpin langsung oleh Nabi Muhammad shallallahu alaibi wa sallam, dengan ini berarti berakhirlah permusuhan kaum Quraisy terhadap kaum muslimin dan manusia berbondong-bondong memeluk agama Allah sehingga dakwah Islam menjadi memiliki banyak pasukan dan peralatan serta kekuatan.

Demikianlah jihad thalab (jihad memerangi setiap aral yang merintangi arus dakwah Islam) akhirnya difardhukan dan setelah Rasulullah shallallahu 'alaihi wa sallam wafat kewajiban ini tidak berubah.Kemudian kewajiban jihad thalab ini diteruskan oleh para khulafaur rasyidin dan para khalifah serta para penguasa setelah mereka. Hingga akhirnya khilafah Utsmaniyah runtuh kurang dari satu abad yang lalu dan kewajiban inipun terhenti sementara sampai kaum muslim memiliki kembali kekuatan untuk menumpas segala bentuk kesyirikan dan kekufuran.

\section{Macam-Macam Jihad}

Jihad bisa dibagi menjadi beberapa berdasarkan muatan yang berbeda. Ini seperti dengan sabda Rasulullah yang berbunyi :

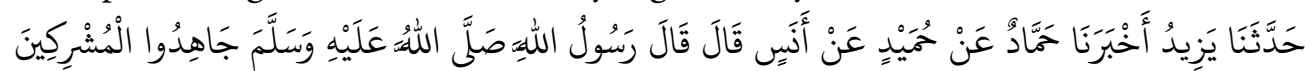

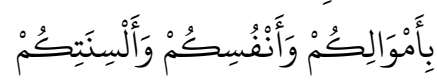

Artinya : "Telah menceritakan kepada kami Yazid berkata, telah mengabarkan kepada kami Hammad dari Humaid dari Anas ia berkata; "Rasulullah SAW bersabda; "Berjihadlah kalian melawan orang musyrik dengan harta, jiwa dan lisan kalian"23.

a) Berdasarkan Alat Yang Dipakai Terbagi Menjadi Tiga Bagian :

1) Jihad dengan jiwa. 
Yakni dengan memasuki kancah peperangan antara ahlul haq versus ahlul batil dalam rangka memenuhi panggilan Allah.

2) Jihad dengan harta.

Yakni mengorbankan hartanya di jalan Allah dengan memberikan komsumsi untuk mujahidin beserta keluarga yang dibawah tanggung jawabnya.

3) Jihad dengan lisan.

Yakni dengan memberikan suara yang bisa mendatangakan maslahah bagi mujahidin atau menghindari bahaya yang akan menimpa mereka, apapun bentuknya ${ }^{24}$.

\section{b) Berdasarkan Sasaran}

Pembagian target sasaran Jihad dibagi menjadi lima:

1) Jihad melawan hawa nafsu

Yakni seseorang mendidik jiwanya untuk taat beragama kepada Allah, meninggalkan syahwat dan fitnah syubhat, serta melkasanakan kewajiban meskipun berat dan tidak disukai jiwa.

2) Jihad melawan syetan

Yakni meninggalkan fitnah syahwat dan subhat yang dihembuskan setan kepada seorang hamba.

3) Jihad melawan orang kafir

Yakni dengan memerangi mereka dan mengorbankan segala yang dibutuhkan dalam peperangan, baik berupa harta, pengalaman, dan lain sebagainya.

4) Jihad melawan orang-orang munafik

Yakni hal ini dilakukan dengan lisan, menegakkan hujjah atas mereka, melarang dan mencegah mereka dari kekafiran yang tersembunyi, membongkar permainan dan maker-makar meraka, serta mewaspadai segala tanduk-tanduk, rencana mereka, dan upaya-upaya mereka yang lain.

5) Jihad melawan orang-orang fasik

Yakni dilakukan dengan tangan, jika tidak mampu, maka dengan lisan. Dan jika tidak mampu maka dengan hati.

\section{c) Berdasarkan Hukumnya}

Ini memiliki dua keadaan berbeda. Pertama, hukum-hukum Jihad turun secara bertahap dalam beberapa fase. Kedua, Jihad memiliki ketetapan hukum dan syariat. Jihad dari segi hukum talah final, hal ini terjadi karena 
sebelum memiliki hukum yang final, hukum Jihad telah melewati empat fase:

Fase pertama, fase ini meliputi seluruh fase Makkah, pada fase itu, orang-orang beriman dilarang memerangi orang-orang kafir, tetapi diperbolehkan berjihad dengan Al-Qur"an dan dakwah yang lurus.

Fase kedua, turunnya fase ini berarti menghapus fase sebelumnya yang memerintahkan mereka menahan tangan mereka, tanpa mewajibkan atau mefardhukan Jihad.

Fase ketiga, dalam fase ini, kaum muslimin diperintahkan hanya memerangi siapa saja yang memerangi mereka dengan meninggalkan orangorang yang tidak memerangi.

Fase keempat, inilah fase diwajibkannya memerangi orang-orang kafir, dimulai dari oang-orang kafir yang lebih dekat dengan kaum muslimin, tindahkan ini telah dilakukan Nabi terhadap orang-orang kafir arab ${ }^{25}$.

\section{Jihad Dan Kerukunan Antar Umat Beragama}

164 ayat jihad perang dalam AL-Qur'an menjadi sangat signifikan terhadap pemahaman dan mplementasi makna dan hakekat dari wahyu ilahiyah yang merupakan landasan awal dari ajaran agama Islam. Disamping itu, Islam itu memiliki konsep yang jelas tentang pola hubungan umat beragam dalam menciptakan satu tatanan sosial yang harmonis dan toleran.

Pemahaman bahwa Islam sebagai agama rahmat bagi seklian alam sudah sewajarnya memberikan tuntuan dan tuntunan dengan memberikan hak serta perlindungan kepada setiap orang untuk bebas memberikan kontribusinya bagi kelangsungan sebuah Negara. Toleransi yang dibangun oleh agama Islam adlah toleransi yang terbuka, bebas, dan persamaan hak. Akhirnya menciptakan kerukunan dalam agama islam adalah tuags dan tujuan fundamental agama, sebuah kesadaran yang muncul dari manusia beragama harus bertemu dalam kerukunan dan persaudaraan daripada permusuhan ${ }^{26}$.

Semangat perdamaian dan kerukunan antar umat beragama yang menjadi dasar dari interpretasi atas ayat-ayat jihad perang akan membuat suatu pola yang dapat memecahkan keberagamaan umat yang hidup dalam suatu wilayah. Membingkai makna dan hakekat kedamaian, keadilan, toleransi, dan nilai-nilai kemanusiaan lainnya dalam kehidupan bemasyarakat.

Dalam kaitan penciptaan kerukunan dan persualan jihad tidak bisa disatukan, sebab persoalan kerukunan menciptakan aman, tenang, damai. Sedangkan jihad (perang) menciptakan pertumpahan darah, penghancuran dan penderitaan. Untuk membingkai persoalan tersebut, perlu sanga tmenyelami 
makna dan hakekat dari firman Allah SWT :

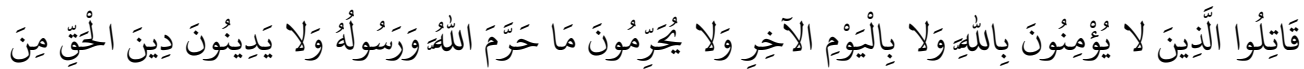

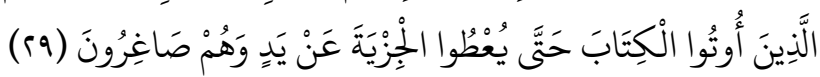

Artinya : "Perangilah orang-orang yang tidak beriman kepada Allah dan tidak (pula) kepada hari Kemudian, dan mereka tidak mengharamkan apa yang diharamkan oleh Allah dan RasulNya dan tidak beragama dengan agama yang benar (agama Allah), (Yaitu orang-orang) yang diberikan Al-Kitab kepada mereka, sampai mereka membayar jizyah ${ }^{27}$ dengan patuh sedang mereka dalam Keadaan tunduk"2s.

Perintah perang dalam ayat ini, bila dipahami secara tekstual berdampak buruk terhadap masa depan kerukunan antar umat beragama. Sebenarnya makan ayat ini tidak berlaku universal, melainkan terkait dengan ruang dan waktu. Kondisi umat Islam saat diturunkannya ayat ayat tersebut, berada dalam suasana yang terpolarisasi secara kenyataan dalam dua kutub. Kutub pertama; orang-orang yang mengikuti Rasulullah SAW, yakni orang-orang yang secara teologis beragama Islam dan secara teologis anti perbudakan serta anti monopoli kekayaan. Kutub kedua; orang-orang yang musyrik menolak dakwah Rasulullah SAW yang secara teologis tidak beragama Islam dan secara teologis pro perbudakan dan monopoli kekayaan. Kondisi saai itu tidak memungkinkan terciptanya kondisi kerukunan. Sebab garis perjuangan masing-masing berbeda, bahkan saling berhadapan. Maka interpretasi ayat tersebut dibingki dalam kondisi perang serta tidak digeneralkan kapan saja dan dimana saja.

Konteks kekinian, dimana umat Islam dan non Islam tidak berada dalam posisi yang saling berhadapan, maka perlu disandingkan dan didialogkan dengan ayat-ayat yang lain yang menganjurkan toleransi, kasih saying, dan tolong menolong antar sesama :

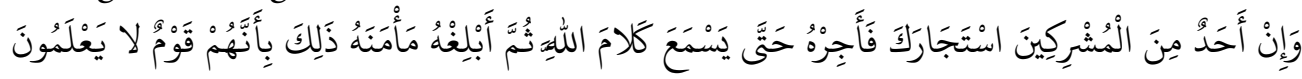

Artinya : "Dan jika seorang diantara orang-orang musyrikin itu meminta perlindungan kepadamu, Maka lindungilah ia supaya ia sempat mendengar firman Allah, kemudian antarkanlah ia ketempat yang aman baginya. demikian itu disebabkan mereka kaum yang tidak mengetahui'29.

Berarti tidak selamanya harus memusuhi non muslim. Tapi ada saat-saat dimana umat Islam justru harus menolong mereka dan bekerjasama. Hal ini tidak terlepas dari AL-Qur'an dan Hadits sebab banyak sekali ayat-ayat yang menjelaskan bahwa kerukunan dan tolerasni itu begitu jelas dan lugas. 
Standarisasi interpretasi ayat-ayat jihad perang dapat dibingkai melalui apa yang dilakukan Rasulullah SAW dengan para sahabatnya dalam membangun kerukunan ${ }^{30}$. Diantara konsep kerukunan yang dipraktekkan Rasululllah dan para sahabat adalah :

1) Penghargaan terhadap perbedaan agama sebagaimana dijelaskan dalam surah Al-Kafirun ayat 1-6, khususnya ayat ke-6.

2) Allah telah menciptakan manusia berbangsa-bangsa dan bersukusuku dimana Islam meletakkann setinggi-tingginya perhargaan terhadap fenomena tersebut. Sebagaimana firman Allah:

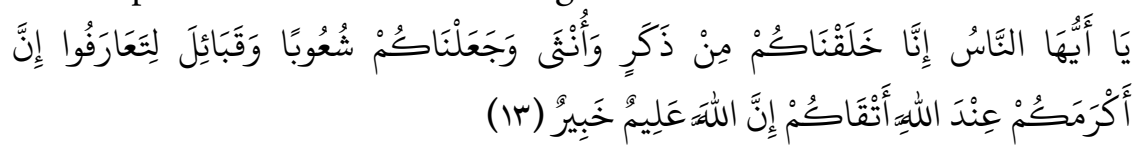

Artinya : "Hai manusia, Sesungguhnya Kami menciptakan kamu dari seorang laki-laki dan seorang perempuan dan menjadikan kamu berbangsa - bangsa dan bersuku-suku supaya kamu saling kenalmengenal. Sesungguhnya orang yang paling mulia diantara kamu disisi Allah ialah orang yang paling taqwa diantara kamu. Sesungguhnya Allah Maha mengetahui lagi Maha Mengenal's1.

Dalam ayat ini ada dua teori yang dapat diperoleh dalam membangun kerukunan yakni; pertama teori persamaan hak bagi manusia (Nadhariyah al-Musawah), yakni persamaan secara universal tanpa membedakan suku, bangsa agama, ras, kedudukan, keturunan dan unsur lainnya. Kedua, dari ayat itu juga dapat dipahami teori pengakuan atas eksistensi bangsa-bangsa (syu'ub) dan suku- suku bangsa (qabail) ${ }^{32}$.

3) Rasulullah SAW bersosialisasi dengan kaum Nasrani, fakta ini dapat dilihat bagaimana beliau berinteraksi dengan pendeta Waraqah bin Naufal yang berani menyatakan simpati dan dukungannya kepada Nabi, bahkan kalau seandainya beliau saat itu masih kuat dan muda ia berani memasang badan untuk membela Nabi Muhammad dalam menyampaikan kebenaran ${ }^{33}$.

4) Membangun hubungan dengan kaum Yahudi dengan pernikahan, diskusi, silaturahmi, bersimpati pada Nabi ketika perang, menginfakkan harta mereka pada Islam dsb.

5) Nabi mempersatukan Suku-suku Arab. Dalam hal ini nabi melakukan konsep mu'akhah (mempersaudarakan) antara kelompok itu dengan adil dan tanpa berat sebelah serta melemahkan satu 
dengan yang lain.

6) Memformat teori Jizyah dan Dzimmah. Untuk menciptakan kerukunan maka Al-Qur'an surat Ali Imran ayat 122 menjelaskan sikap terhadap pajak dan perlindungan bagi orang kafir. Semangat yang dapat ditangkap dari ayat ini adalah bahwa secara moral bahwa teori Jizyah dan Dzimmah adalah diakuinya eksistensi agama-agama dan terciptanya kerukunan antar umat beragama, dimana kelompok mayoritas harus melindungi minoritas.

7) Merealisasikan persoalan makanan dan minuman. Untuk mengakrabkan dan merukunkan antar pemeluk agama, Al-Qur'an memberikan pedoman dalam hal makanan dan minuman sebagaimana tertulis dalam Q.S Al-Maidah ayat 5. Ayat ini dipahami oleh para ulama sebagai kebolehan memakan makanan dan minuman kaum ahli kitab berupa daging dan dan lainnya halal dimakan orang islam, meskipun dalam menyembelih binatang itu mereka tidak menyebutkan nama Allah $^{34}$. Demikian pula ayat ini membolehkan menikahi wanita ahli kitab seperti pernikahan Nabi dengan Maria AlQibthiyah yang beragama Nasrani.

Wujud dari Kerukunan antar umat beragama adalah :

1. Saling hormat menghormati kebebasan menjalankan ibadah sesuai dengan agamanya.

2. Saling hormat menghormati dan bekerjasama intern pemeluk agama, antar berbagai golongan agama dan umat-umat beragama dengan pemerintah yang sama-sama bertanggung jawab mmbangun bangsa dan Negara.

3. Saling tenggang rasa dan toleransi dengan tidak memaksa agama kepada orang lain.

Kerukunan hidup umat beragama di Indonesia dipolakan dalam Trilogi Kerukunan yaitu:

1. Kerukunan intern masing-masing umat dalam satu agama Ialah kerukunan di antara aliran-aliran / paham-paham /mazhab-mazhab yang ada dalam suatu umat atau komunitas agama.

2. Kerukunan di antara umat / komunitas agama yang berbeda-beda Ialah kerukunan di antara para pemeluk agama-agama yang berbedabeda yaitu di antara pemeluk islam dengan pemeluk Kristen Protestan, Katolik, Hindu, dan Budha. 
3. Kerukunan antar umat / komunitas agama dengan pemerintah Ialah supaya diupayakan keserasian dan keselarasan di antara para pemeluk atau pejabat agama dengan para pejabat pemerintah dengan saling memahami dan menghargai tugas masing-masing dalam rangka membangun masyarakat dan bangsa Indonesia yang beragama.

\section{Kesimpulan}

Akhirnya, Setelah membahas secara menyeluruh dapatlah diambil kesimpulan bahwa Jihad menurut para ulama adalah mengusahakan secara optimal baik kemampuan maupun tenaga dalam berperang di jalan Allah. Baik oleh madzhab Hanafi, Hambali, Maliki dan Syafi'i mengartikan jihad sebagai perang melawan orang kafir untuk menegakkan agama Allah SWT.

Ayat-ayat jihad serta haditsnya merupakan nash yang memberi semangat kepada umat Islam untuk memperjuangkan Agama dan mendapatkan mati yang mulia, tapi realita sekarang ini umat dihadapkan kepada kehidupan bermasyarakat dimana kerukunan antar umat beragama yang saling hidup berdampingan.

Jihad yang dilakukan oleh para ulama adalah untuk membebaskan diri dari penindasan para penjajah dengan cara pelawanan sedangkan jihad atau yang di sebut dengan pejuang kemerdekaan (heroic terrorism) yang dilakukan oleh para teroris (horrific terrorism) merupakan upaya serangan secara fisik kepada orang-orang kafir, serangan dan aksi ini seolah memiliki dasar hukumnya namun pemahaman yang hanya secara tekstual saja mengakibatkan terbunuhnya manusia tanpa pandang bulu.

Tidak Ada Paksaan dalam Beragama (Yûnus,10/51:99) dan (AlBaqarah,2/87:256). Allah sebagai sebenar-benarnya pendidik dalam Pendidikan Islam berkuasa atas segala hambanya, sebab itu pemaksaan tidak diperbolehkan dalam agama. Pendidikan Islam merupakan jalan yang benar, pilihan untuk tidak memilih agama Allah sesudah datangnya kejelasan akan dipertanggung jawabakan dihadapan-Nya.

\section{Daftar Pustaka}

Al-Khathiib, Haasyiyah al-Bujayrimi ,alaa Syarh al-Khathiib, juz IV

Al-Mascaty, Himy Bakar, Panduan Jihad untuk Aktivitas Gerakan Islam,

Hasbi, H. M. Ridwan, "Membingkai Ayat-Ayat Jihad Perang Dalam Kerukunan Umat Beragama”, Dosen Fakultas Ushuluddin UIN SUKA Riau.

Ilyasy, Muhammad, Munah al-jaliil, Muhktashar Sayyidi Khaliil, juz III 
Mandzur, Ibnu, Lisan al-Arab (Kairo Ad-Dar al- Mishriyyt.t)

Marijan, Kacung, “Terorisme dan Pesantren; Suatu Pengantar”, dalam Muhammad Asfar (Ed.), Islam Lunak, Islam Radikal; Pesantren, Terorisme dan Bom Bali, (Surabaya: Pusdeham dan JP Press, 2003)

Pustaka, Lidwa, "Lembaga Ilmu Dakwah dan Publikasi Sarana Keagamaan”. Ensiklopedia Hadits, Kitab 9 Imam. Jl Naga Raya no 17. B 001/018 Klender, Kec Durensawit. Jakarta Timur 13460

Qudaamah, Ibn, al-Mughniy, juz X

Qutub, Said, Tafsir Fi Zhilal al-Quran, (Bairut: Dar al-Syuruq, 1990).

Rahardjo, M. Dawam, Ensiklopedi Al-Qu“an, Tafsir Sosial Berdasarkan KonsepKonsep Kunci, Jakarta: Paramadina, 1996

Ramadhun, Abdul Baqi, Jihad jalan kami, terj.Imam Fajaruddin, Solo, Era Intrmedia, 2002

Republik Indonesia, Departemen Agama, Al-Qur'an dan Terjemahan

Salenda, Kasjim, Terorisme dan Jihad (Dalam Persepektif Hukum Islam), PT Raja Grafindo Persada, Jakarta, 2009

Samudra, Imam, Aku melawan Teroris, Solo, Jazera, 2004

Shihab, M. Quraish Wawasan Al-Qur'an : Tafsir Maudhu'i atas Berbagai Persoalan Umat, Bandung : Mizan, 1996

\section{Catatan Akhir}

1. Kasjim Salenda, Terorisme dan Jihad (Dalam Persepektif Hukum Islam), PT Raja Grafindo Persada, Jakarta, 2009, 21

2. Kacung Marijan, “Terorisme dan Pesantren; Suatu Pengantar”, dalam Muhammad Asfar (Ed.), Islam Lunak, Islam Radikal; Pesantren, Terorisme dan Bom Bali, (Surabaya: Pusdeham dan JP Press, 2003), 201.

3. Imam Samudra, Aku melawan Teroris, Solo, Jazera, 2004, 108.

4. Ibnu Mandzur, Lisan al-Arab (Kairo Ad-Dar al- Mishriyyt.t), 109

5. Lihat lagi Q.S. Al-Maidah/5:53, Q.S. Al-an am /6:109, Q.S.An-Nahl /16:38, Q.S. AnNukr /24:53, dan Q.S. Al-Fathir /35:42

6. Lihat lagi Q.S. At-Taubah /9:79

7. M.Quraish Shihab, Wawasan Al-Qur'an : Tafsir Maudhu'i atas Berbagai Persoalan Umat, Bandung: Mizan, 1996, 501.

8. M. Dawam Rahardjo, Ensiklopedi Al-Qu"an, Tafsir Sosial Berdasarkan Konsep-Konsep Kunci, Jakarta: Paramadina, 1996, 517.

9. M. Quraish Shihab, Wawasan Al-Qur"an, 411.

10. M. Dawam Rahardjo, Ensiklopedi Al-Qu"an, 329.

11. Himy Bakar al-Mascaty, Panduan Jihad untuk Aktivitas Gerakan Islam, 23.

12. Muhammad Ilyasy, Munah al-Jaliil, Muhktashar Sayyidi Khaliil, juz III, 135. 
13. Al-Khathiib, Haasyiyah al-Bujayrimi ,alaa Syarh al-Khathiib, juz IV, 225.

14. Ibn Qudaamah, al-Mughniy, juz X, 375.

15. H.R Bukhari No. 1834 versi Fathul Baari, Kitab Haji. Bab Tidak Boleh Berperang di Makkah.

16. H.R Muslim No.71 versi al-'Alamiyah, No.50 versi Syarh Sahih Muslim. Kitab iman, Bab penjelasan bahwa mencegah kemungkaran adalah bagian dari iman, dan bahwa iman itu bertambah.

17. H.R an-Nasa'I No.3052 versi al-'Alamiyah dan No.3103 versi Maktabatu al-Ma'arif Riyadh, Kitab Jihad. Bab Rukhsah tidak berangkat bagi yang punya dua anak.

18. H.R Bukhari No.2782 versi Fathul Baari, Kitab Jihad dan Penjelajahan. Bab Keutamaan Jihad.

19. QS. al-Furqon : 51-52. Departemen Agama R.I, Al-Qur'an dan Terjemahan

20. QS. An- Nisa, ayat 77. Departemen Agama R.I, Al-Qur'an dan Terjemahan

21. QS. Al-Hajj, 39. Departemen Agama R.I, Al-Qur'an dan Terjemahan

22. QS. Al-Baqarah, 190. Departemen Agama R.I, Al-Qur'an dan Terjemahan

23. H.R Ahmad No. 11798, Kitab Sisa Musnad Sahabat Yang Banyak Meriwayatkan Hadits. Bab Musnad Anas bin Malik r.a.

24. Abdul Baqi Ramadhun, Jihad jalan kami, Solo: Era Intrmedia, 2002, 20.

25. Abdul Baqi Ramadhun, Jihad jalan kami, 24-25.

26. H.M.Ridwan Hasbi, "Membingkai Ayat-Ayat Jihad Perang Dalam Kerukunan Umat Beragama”, Hal 7. Dosen Fakultas Ushuluddin UIN SUSKA Riau.

27. Jizyah ialah pajak per kepala yang dipungut oleh pemerintah Islam dari orang-orang yang bukan Islam, sebagai imbangan bagi keamanan diri mereka.

28. QS. At-Taubah, 29. Departemen Agama R.I, Al-Qur'an dan Terjemahan

29. QS. At-Taubah : 6. Departemen Agama R.I, Al-Qur'an dan Terjemahan

30. H.M.Ridwan Hasbi, "Membingkai Ayat-Ayat Jihad Perang Dalam Kerukunan Umat Beragama”, Hal 8. Dosen Fakultas Ushuluddin UIN SUSKA Riau.

31. QS. Al-Hujraat : 13. Departemen Agama R.I, Al-Qur'an dan Terjemahan

32. Said Qutub, Tafsir Fi Zhilal al-Quran, (Bairut: Dar al-Syuruq, 1990)

33. Muhammad Sa`id Ramadhan al-Buthiy, Ibid., hal. 96

34. Dalam kitab Tafsir Ibnu Katsir dijelaskan "Masalah ini telah disepakati di kalangan para ulama, bahwa sesungguhnya sembelihan ahli kitab itu halal bagi kaum muslim, karena mereka pun mengharamkan sembelihan yang diperuntukkan bukan selain Allah dan dalam sembelihan mereka tidak disebutkan kecuali hanya nama Allah, sekalipun mereka berkeyakinan terhadap Allah mereka ketika menyembelih mereka mengatakan; Maha Suci lagi Maha Agung 